\title{
Ornithine Decarboxylase and $S$-Adenosyl Methionine Decarboxylase in Skin Tibroblasts of Normal and Cystic Fibrosis Patients
}

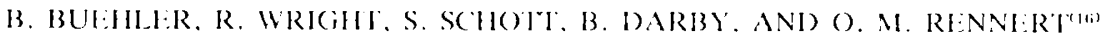 \\ Division of Cenctics, Ludocrinology, and M/tabolism, Departments of Pediatrics, Biochemistry, and Neuroscience. \\ University of Florida College of Medicine and University of Florida Sumland Research Laboratorics, Ciamesville, \\ Horida, USA
}

\section{Summary}

The key enzymes in the synthesis of the naturally occurring polyamines, ornithine decarboxylase (OD)C and $S$-adenosyl me: thionine (SAMI) decarboxylase, were investigated during cell grow th and aging in fibroblast cultures from normal patients and patients with cystic fibrosis. A linear correlation between increased $S$-adenosyl methionine activity and putrescine concentration was apparent in all cell lines. A putrescine concentration of $0.8 \mathrm{mM}$ was optimal for enhancement of $\mathrm{S} \mathrm{A} \mathrm{M}$ decarboxylase activity.

The passage number of the cell line correlated inversely with maximal putrescine-stimulated SAM decarboxylase activity, earlier passage numbers having the highest specific activity (Fig. 1). No significant differences in basal or putrescine-stimulated $S \mathrm{~A} M$ decarboxylase activity nere noted between normal fibroblast cultures and cells from patients with cystic fibrosis (Fig. 2). SAMI decarboxylase activity increased as the cell lines approached confluence. Activity was lowest during exponential growth (Fig. 3). ODC activity was increased during carly exponential growth and fell as cells reached contluence (Fig. 4). No differences in ODC activity and putrescine inhibition between the mormal and cystic filorosis cell cultures at equivalent points of exponential growth were noted.

\section{Speculation}

Although there are definite alterations of polvamine levels in patients with cystic fibrosis, no abnormalities in ornithine decarboxylase or $S$-adenosyl methonine decarboxylase were found in cystic fibroblasts (fig. 5). Differences in polyamine biosynthetic activity appeared to be a function of cell age. Therefore, it is postulated that polyamine abnormalities in cystic fibrosis are caused by enzymes other than $S_{X} \mathbf{M}$ or ornithine decarboxylase. The polyamine abnormalities may relate to abnormalities in the metabolism of polyamines (e.g., acetylation or catabolism) or be a conseguence of increased in vivo syuthesis secondary to humoral factors which have not yet been identified.

Table 1 . Stimulation of S-ade'nosyl methionine decarborylase activity by $2.5 \mathrm{~mm}$ partescine

$\begin{array}{ccc}\text { Cill line } & \text { Activity relative to } \\ & \text { Passage no. } & \text { basil level -fold } \\ & 6 & 38,45 \\ & 28 & 39,17,22 \\ & 8 & 30,40 \\ \text { rosis } & 11 & 20,21\end{array}$

Several investigators $(1,9,12)$ have indicated that polyamine level in sera and urine closely reflect abnormal discase states in humans. In meoplastic discises, polyamine levels reflect the rapid turnover rate of celts (1.3) and the potential indices of therapeutic efficacy (10, 13). In cystic fibrosis paticnts, abnormal blood concentrations of spermidine have been found (7). and these levels may be uscful in diagnosis.

Previous in vitro studies of polyamine biosynthetic pathways (sec Fig. 5) have utilized rat prostate and tumor cells $(3,4)$, but no extensive studies in human libroblast cultures have been

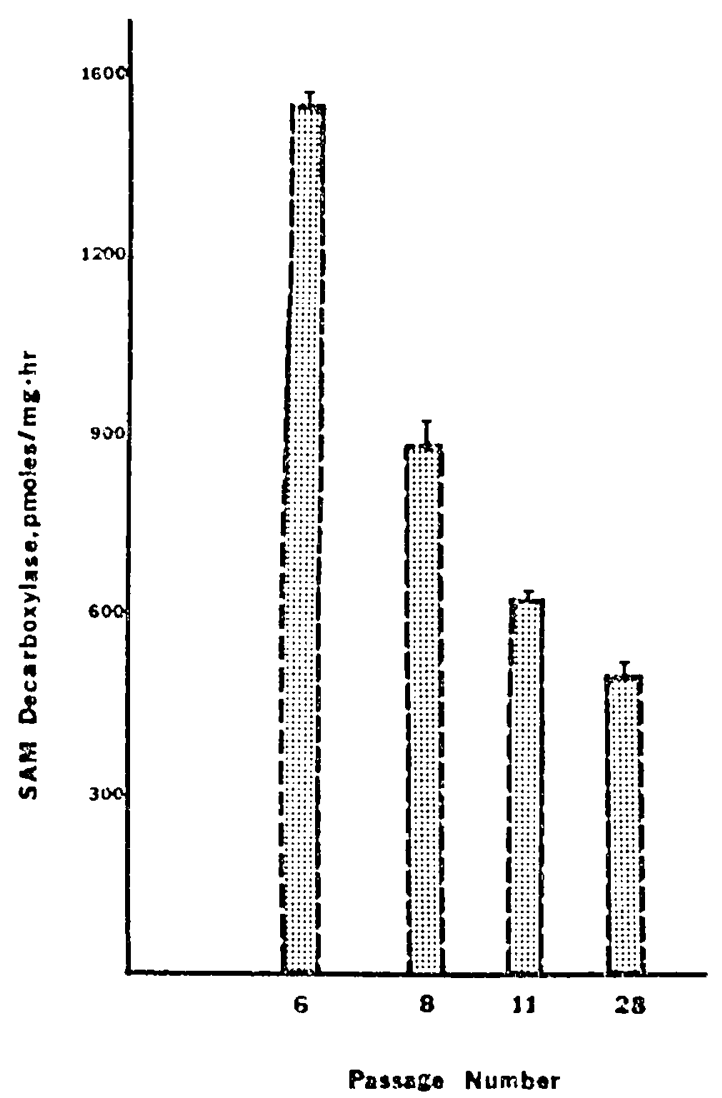

Fig. 1. The potential S-atenosyl methionine $(S A M)$ decarboxylase atevity in the presence of putrescine decreased with increasing numbers of cultute passiges. The concentration of putrescinc was $2.5 \mathrm{~m}$. $\mathrm{N}$ for all cultures studied. lateh point represents the arerage of two separate experiments except passige 28 which is the mein of four experincents. Passages 8 and 11 are cystic fibrosis fibroblatsts whereas passages 6 andel 28 are normal fibroblasts. 


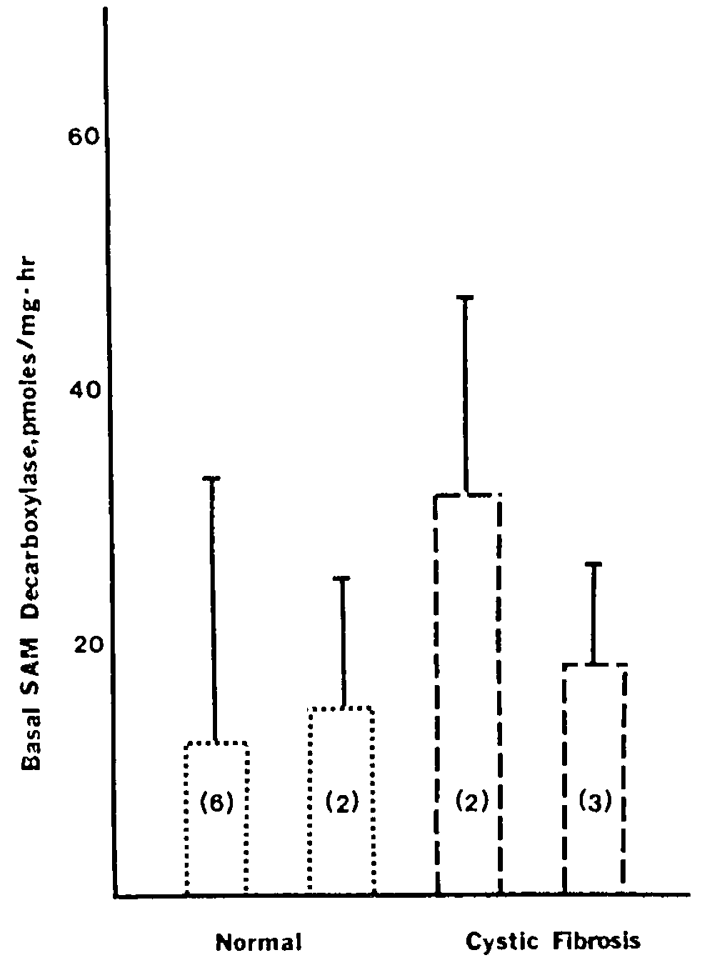

Fig. 2. Basal $S$-adenosyl methionine $(S A M)$ decarboxylase specific activity in cystic fibrosis and normal fibroblasts. Each value is the average of two to six experments per culture. The number of experiments is given as $(N)$ in bar graph. From left to right the passage number of the bar graphs for the control cultures are 28 and 6 . and for the cystic fibrosis cultures 11 and 8 , respectively. reported. In this report, the key enzymes in the synthesis of the naturally occurring polyamines, ODC and SAM decarboxylase, were investigated during cell growth and aging in fibroblast cultures from normal patients and paticnts with cystic fibrosis (CF).

\section{MATIERIALS ANI) MIETHODS}

Cultured skin fibroblasts from two normal $\mathrm{CF}$ male adults, three normal male infants, and four children with (age 2-5 years) were grown in $75-\mathrm{cm}^{2}$ Falcon flasks at $37^{\circ}$ in a $5 \% \mathrm{CO}_{2}$ atmosphere. The cells were cultured in $15 \mathrm{ml}$ Eagle's minimum essential medium with $10 \%$ or $20 \%$ fetal calf serum, penicillin (100 $\mu \mathrm{g} / \mathrm{ml})$, streptomycin $(100 \mu \mathrm{g} / \mathrm{ml})$, fungizone $(25 \mu \mathrm{g} / \mathrm{ml})$ ( $1 \%$ antibiotic antimycotic mixture), $10 \mathrm{mM}$ HEPES buffer, and $1 \%$ nonessential amino acids with $2 \mathrm{mM}$ L-glutamine. All culture materiats were purchased from Gibco. Confluent flasks were trypsinized and split $1: 2$ or $1: 324 \mathrm{hr}$ before assay. At the time of assay, $2 \mathrm{ml} 0.1 \mathrm{M}$ sodium phosphate buffer, pli 7.2, were added to each flask, and the cells were removed by scraping with a rubber policeman. Cells from 20) flasks were harvested and eentrifuged at $90(0) \times g$ for 10 min at $4^{\circ}$. The resulting pellet was resuspended in $5.5 \mathrm{ml} 0.1 \mathrm{M}$ sodium phosphate buffer. pH 7.2, with $5 \mathrm{mM}$ dithothreitol and $0.05 \mathrm{mill}$ pyridoxal phosphate. The cell suspension was freeze-thawed twice with liquid $\mathrm{N}_{2}$. After frecze-thawing, the mixture was spun at 25,000$) \times g$ for $15 \mathrm{~min}$ at $t^{\circ}$ in a Beckman LD3-40 ultracentrifuge. The supernatant and pellet were separated and the final volume of supernatant brought to a (i-ml volume with $1 \mathrm{mM}$ IEDTA (0.5 ml added). All assays were performed with this preparation. The assays were performed in triplicate on at least three different occasions and gate reproducible results with a variation of $10 \%$ or less.

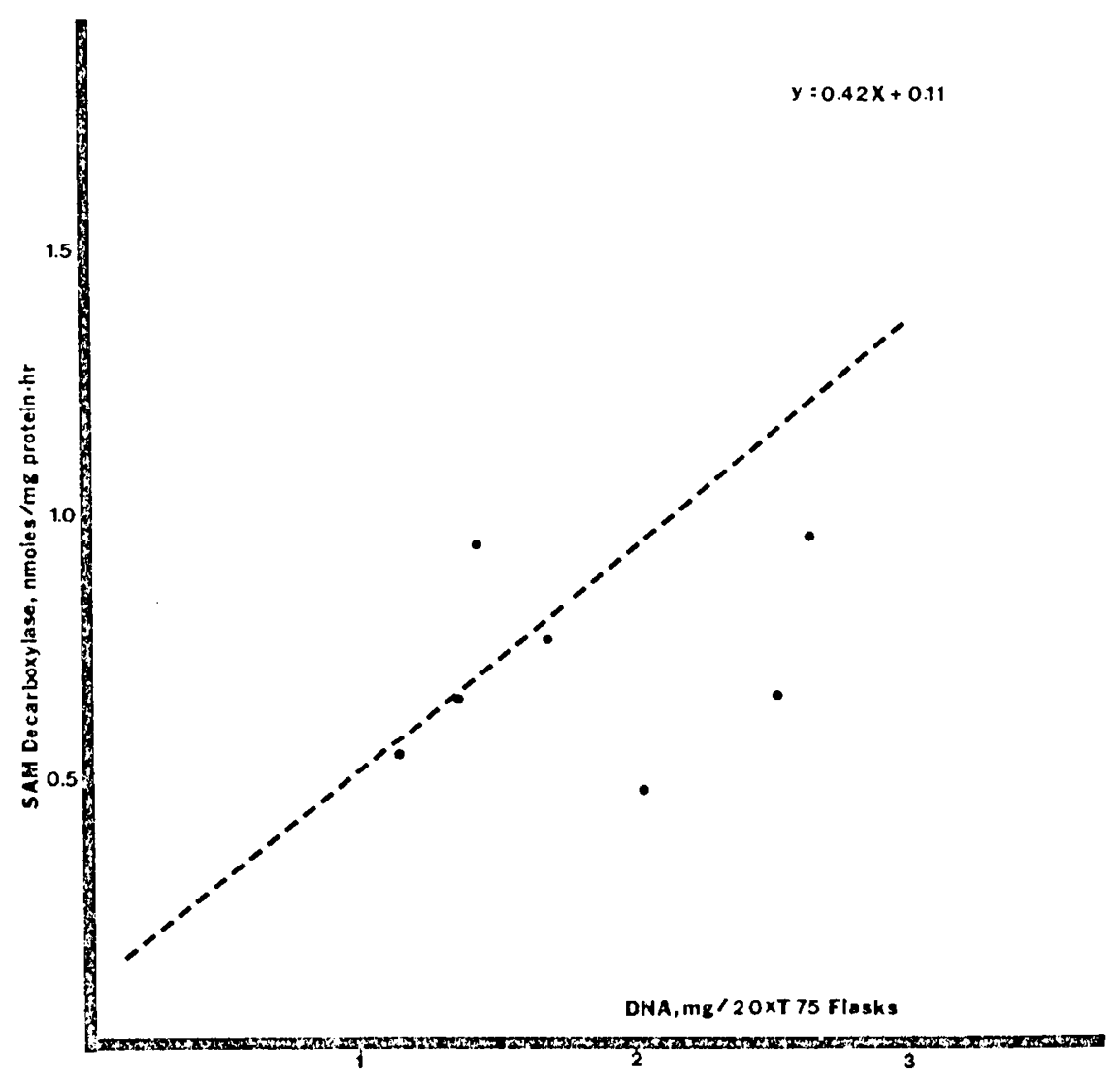

Fig. 3. Putrescinc stimulated $S$-adenosy methionine $(S A, Y)$ decarboxylase activity is a function of DNA content. Since DNA content/per cell is constant, the transition of cultured fibroblasts from the exponential growth phase to the stationary phatse is expressed als a function of the IDNA concentration per culture flask. Increasing DNA concentration is synonymous wh time since passage of the innoculum or with doubling time. SAM decarboxylase specific activity increases is both cystic and normal cells transit from exponential growth to confluence (nonproliferative state) 


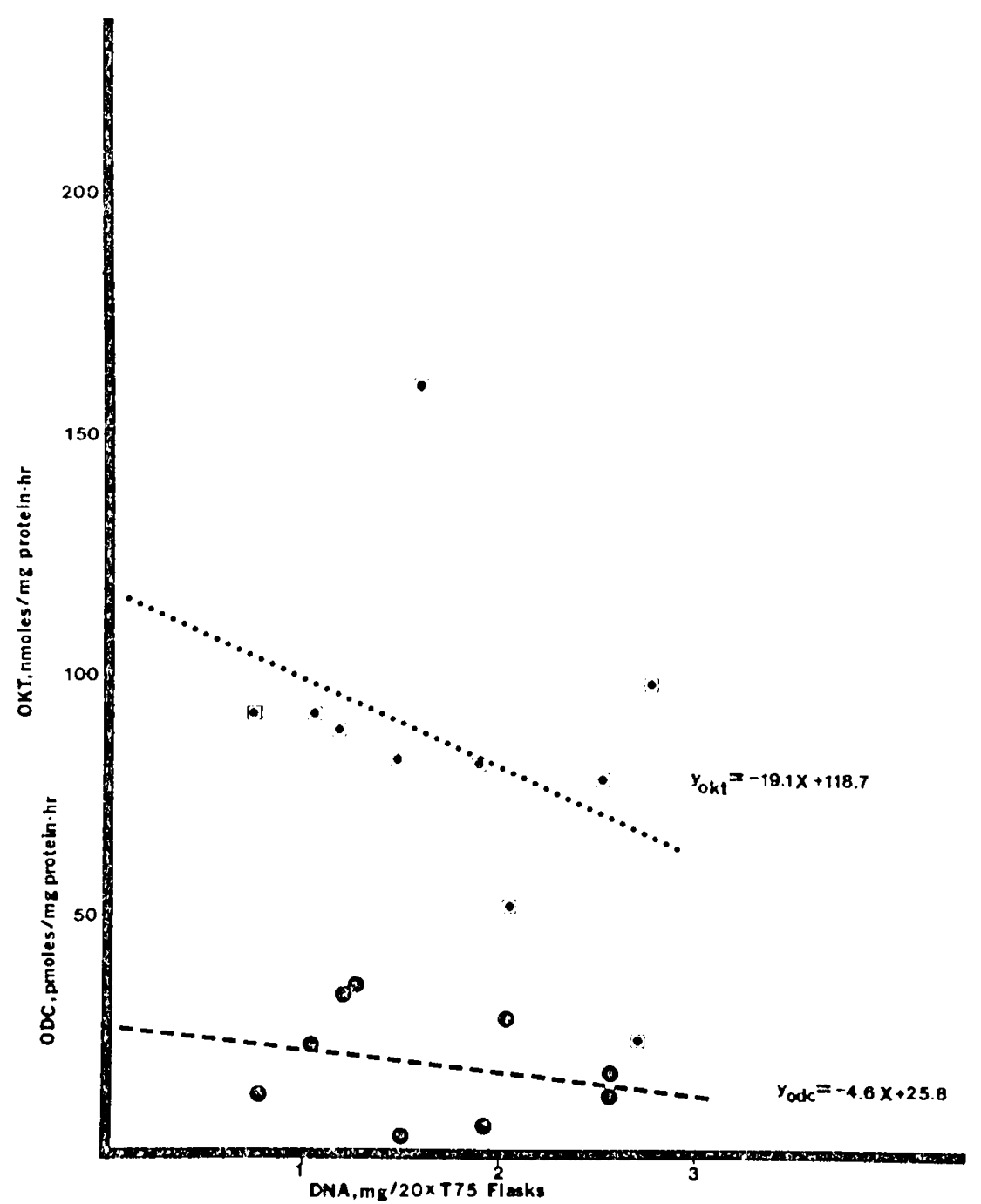

Fig. 4. The transition of cultured fibroblasts from exponential growth towards confluence is characterized by increasing 1$) \mathrm{N} A$ concentration per culture vessel. Both ornithine carboxylase $\left(O D C C^{\prime}\right)$ and ornithine-ketoacid transaminase $(O K T)$ specifie activity decrease as cellular proliferation decreises.

SAM decarboxylase assaly was accomplished with $0.5 \mathrm{ml}$ enzyme supernatant incubated with 5 el S-atchosyl-[carboxy${ }^{1.4} \mathrm{C}$ methionine. ${ }^{14} \mathrm{C}-\mathrm{lab}$ eled SAM1. $7.5 \mu \mathrm{Ci} / \mathrm{mm}$ ) (New England Nuclear (orporation). 5.0 $\mathrm{mM} 100.01 \mathrm{mM}$ putrescine and 0.1 $\mathrm{M}$ sodium phosphate buffer, pH 7.2, in a final volume of $1 \mathrm{ml}$ and a final concentration of $0.25 \mu \mathrm{g}$ of $\left.\right|^{\mathrm{H} C} \mathrm{C}$ SSAM. Duplicate blanks contained boiled enzyme. The mixture was incubated at $37^{\circ}$ in a 20 -ml scintillation vial. A no. 1 Whatman filter paper disk was cut to fit into the cap and saturated with $0.1 \mathrm{ml}$ Hyamine to trap $\left(O_{2}\right.$. The $37^{\circ}$ water bath was kept in a $37^{\circ}$ environmental chamber to prevent condensation of liequid at the rim of the vial. After $30 \mathrm{~min}$, the reaction was stopped by addition of $1 \mathrm{ml}+10 \%$ trichloroacetic acid, and the tightly capped vial was gently shaken for $60 \mathrm{~min}$ at room temperature to release all $\mathrm{CO}_{2 .}$. The Hyamine-impregnated disk was removed and placed in $10 \mathrm{ml}$ of $A$ guatsol scintillation counting fluid from Now England Nuclear Corporation. Background counts of Hyaminesaturated filter paper and Ayuasol were $34 \mathrm{cpm}$. Scintillation counting was done in a Hewlett Packard Tri-Carb scintillation spectrometer, model 3.320 .

For the assay of ODC , the preparation was incubated at $37^{\circ}$ using the above outlined Hyamine-saturated filter paper disk method. Enzyme supernatant $(0.5 \mathrm{ml})$ was incubated with $10 \mu$ l [carbory-14Cornithine, specific activity $=54 \mu \mathrm{Ci} / \mathrm{mmol}$. The assay was incubated for $60 \mathrm{~min}$ and stopped by addition of 0.5 ml trichloroacetic acid and the vial gently shaken for 60 min to release all labeled $\mathrm{CO}_{2}$. Blanks contained boiled enzyme.
The activity of the enzyme, ornithine- $x$-hetoaminotransferase $(\mathrm{OKT})$, which is not directly involved in polyamine synthesis, was assayed by adding $0.2 \mathrm{ml}$ supernatant to $0.6 \mathrm{ml}$ sodium. I $\mathrm{mM}$, phosphate buffer with $5 \mathrm{mM}$ dithiothreitol, $0.5 \mathrm{mM}$ pyridoxal phosphate, and $1.5 \mathrm{mM}$ EDTA (pH 7.2) in a conical

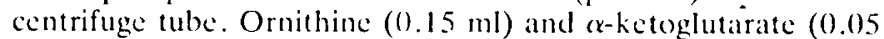
$\mathrm{ml}$ ) were added, mixed, and the tubes incubated at $37^{\circ}$ for $2 \mathrm{hr}$. The reaction was stopped by addition of $0.6 \mathrm{ml} 10 \%$ trichloroacetic acid and $0.6 \mathrm{ml} 1 \%$ 2-aminobenzaldehyde. The optical density was determined at a wavelength of $443 \mathrm{~nm}$ in a Bausch and Lomb Spectronic 600 .

DNA concentration wats determined on $0.1 \mathrm{ml}$ of the freezethawed suspension by the method of Richards (10) and protein content of the enzyme preparations was determined using the method of Lowry et al. (6). Since the amount of DNA in each cell is constant, an increase in measured total DNA per culture flask reflects increased cell number or density. Microseopic inspection of several culture flasks established confluency at a cell density of $3 \times 10^{7}$ cells/75-cm² flask. The DNA measured in 20 confluent $7.5-\mathrm{cm}^{2}$ culture flasks was approximately $2.5 \mathrm{mg}$.

\section{RESULTS}

Basal SAM decarboxylase activity without addition of putrescine was reproducibly detectable at $15-50 \mathrm{pmol} / \mathrm{mg} \mathrm{prote} i \mathrm{~h} / \mathrm{hr}$. The addition of putrescine to the reaction mixlure increased enzyme act vity 17-45 times in both normal and cystic fibrosis 
Table 2. (Mnithine decarberylase (ODC) activity in normal and cystic fibrosis coll lines'

\begin{tabular}{|c|c|c|c|}
\hline Coll line & Passage no. & $\begin{array}{l}\text { ODC activity, } \\
\mathrm{pmol} / \mathrm{mg} \text { pro- } \\
\text { cin } \cdot \mathrm{hr}\end{array}$ & $n^{1}$ \\
\hline \multirow[t]{4}{*}{ Normal } & 6 & 27 & 3 \\
\hline & 8 & $41)$ & 3 \\
\hline & 17 & 25 & 1 \\
\hline & 28 & 55 & 6 \\
\hline \multirow[t]{2}{*}{ Cystic fibrosis } & 8 & 38 & 3 \\
\hline & 11 & 65 & 3 \\
\hline \multicolumn{4}{|c|}{${ }^{1}$ Number of experiments. } \\
\hline \multicolumn{4}{|c|}{$\begin{array}{c}\text { Table 3. Inhibition of ornithine decarboxylase (o) () by } \\
\text { putrescine, } 2.5 \mathrm{~mm}\end{array}$} \\
\hline Cell line & Passatge no. & \multicolumn{2}{|c|}{ Co of basal activity, $\bar{x}^{\prime}$} \\
\hline Normal & & \multicolumn{2}{|c|}{34} \\
\hline$B O R$ & 14 & \multicolumn{2}{|c|}{32} \\
\hline$N I S$ & 32 & \multicolumn{2}{|c|}{48} \\
\hline $\mathrm{MCO}$ & 15 & \multicolumn{2}{|c|}{24} \\
\hline De't & 17 & \multicolumn{2}{|c|}{46} \\
\hline De'B & 18 & \multicolumn{2}{|c|}{21} \\
\hline Cystic fibrosis & & \multicolumn{2}{|c|}{48} \\
\hline \multirow[t]{3}{*}{$H C^{2} A$} & 12 & \multicolumn{2}{|c|}{48} \\
\hline & 14 & \multicolumn{2}{|c|}{58} \\
\hline & 16 & \multicolumn{2}{|c|}{39} \\
\hline
\end{tabular}

'X Mean.

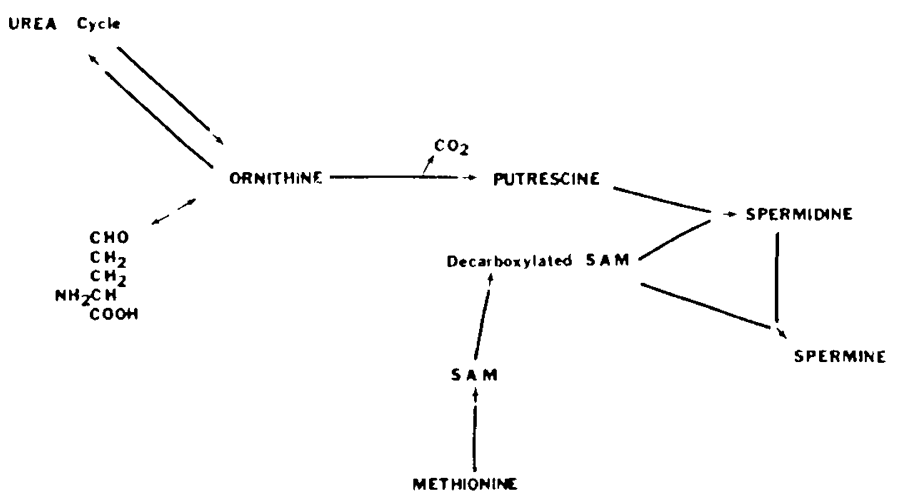

Fig. 5. Biosynthetic pathway of polyamines. SAM: S-adenosyl methionine.

cell lines (Table 1). A lincar correlation between increased SAM decarboxylase activity and lincar correlation between increased SAM decarboxylase activity and putrescine concentration was apparent. A putrescine concentration of $(0.8 \mathrm{mM}$ was optimal for enhancement of $S A M$ decarboxylase activity.

The passage number of the cell line correlated inversely with maximal putrescine-stimulated SAM decarboxylase activity, earlier passage numbers having the highest specific activity (Fig. 1). No significant differences in basal SAM decarboxylase activity were noted between normal fibroblast cultures and cells from patients with CF (Fig. 2).

The mean basal SAN decarboxylase for eight control cultures and five age-matched and passage number-matched cystic fibrosis cultured fibroblasts assayed as released radiolabeled $\mathrm{CO}_{2}$ from $S$-adenosyl methionine showed no difference between $\mathrm{CF}$ and control cultures. SAM decarboxylase activity increased as the cell lines approached confluence. Activity was lowest during exponential growth (Fig. 3). ODC activity was increased during early exponential growth and fell as cells reached confluence (Fig. 4). No differences in ODC activity between the normal and cystic fibrosis cell cultures at equivalent points of exponential growth were noted (Table 2).

As noted in rat prostate (5), the addition of putrescine to human fibroblast enzyme supernatant inhibited the ODC activity; we found 75-100\% inhibition of basal activity at $5 \mathrm{mM}$ and $50-80 \%$ inhibition at $2.5 \mathrm{mM}$ concentrations of putrescine. In a preliminary study no difference in the effect of putrescine was found between the different fibroblast cultures if the growth phase wals equivalent (Table 3 ). Ornithine $\alpha$-ketoaminotransferase. an enzyme which uses ornithine as a substrate but is not directly involved in the polyamine pathways, was found to have equivalent activity in cystic fibroblasts and normal fibroblasts.

Ornithinc-ketoacid transaminase (OKT) activity was monicored because it is an enzyme uninvolved in polyamine biosynthesis that is easily determined in cultured human fibroblasts derived from skin (8). OKT activity is proportional to the number of eclls present but is not known to be influenced by the intermediates of polyamine biosynthesis. The negative slope. $Y_{1 k \mathrm{r}}=19.1 \mathrm{X}+118.7$, found by lincar regression (Fig. 4) of OKT activity plotted against IDNA, indicates that the activity level of this conzme also decreases as the DNA amount reaches maximum levels, $i . e^{\prime}$, at cell confluence.

\section{DISCUSSION}

As human fibroblast cell cultures approach confluence, detectable differences in the activity of key enzymes in the production of polyamines are noted. During carly exponential growth of human fibroblast cultures. there is a measurable increase in the activity of $O D C$. This results in increased production of putrescine, the substrate for spermine and spermidine synthesis (Fig. 5). With increased putrescine production, the rate-limiting step for spermine and spermidine synthesis becomes the decarboxylation of SAM. SAM decarboxylase activity is lowest during carly exponential cell growth, increasing as cells achicve confluence. As demonstrated in this report, increasing putrescine concentration also decreases in in vitro activity of ODC in human fibroblasts (2).

As demonstrated in Figure 1 , the age of a cell line as reflected by passage number correlates with the maximal putrescine-stimulated SAM decarboxylase activity better than the age of the patient or whether the patient has cystic fibrosis. The observations that basal ODC and SAM decarboxylase activity are similar for normal and cystic fibrosis cultures indicate that abnormalities in spermidine concentration noted in cystic fibrosis patients are probably not due to an inlerent abnormality in this component of the biosynthetic pathway.

\section{CONCLUSION}

The key polyamine biosynthetic enzymes, $S$-adenosyl methionine decarboxylase and ornithine decarboxylase, were investigated in normal and CF fibroblasts. No differences were observed in basal SAM decarboxylase and ornithine decarboxylase activity. Inhibition of $O D C$ by putrescine and stimulation of SAM dearboxylase activity by putrescine showed parallel of fects for mormal and CF fibroblast encyme preparations.

\section{RLEERENCES AND NOTES}

1. Bachrach. U.: Function of Naturally Occurring Polyamines (Academic Press, Now York, 1973).

2. Clark, J. L., and Fuller, J. L.: Regulation of ornithine decarboxylase in $3 \mathrm{r} 3$ cells by putrescinc and spermidine: Indirect evidence for transtational control. Biochemistry. 14: $44013(1975)$.

3. Hamonen, P.: Inzymic decarboxylation of S-adenosyl L. methonine in rat liver: Possible interaction of putrescine with the prosthetic group. Acta Chem. Scand. $|A|, 29: 295(1975)$.

4. Hogan. B. L. M.: leffect of grewth conditions on the orinthine decitrboxylase activity of rat hepatoma cells. Biochem. Biophys. Res. Commun., 45: 301 (1971).

5. Jïnne, J., and Höltti. L.: Regutation of ornithine decarboxylase activity by putrescine and spermidine in rat liver. Biochem. Biophys. Res. Commun., 61: $399(1974)$. 
6. Lowry, (). H.. Roscbrough, N. J.. Farr, A. L.. and Randall, R. J.: Protcin meitsurement with the Folin phenel reagent. J. Biol. (hem., /93: 20.5 (1951).

7. Rennert, (). M.. Frias, J. . and LaPointe, I).: In: J. A. Mangos: Fundamentat Problems of Cystic Fibrosis and Related Diseases. pp. 41-52 (Intercontinental Medical Books, New York, 1973)

8. Rennert, O., Garnica, A., and Chan, W. Y.: Hyperornithinemia and hyperammonemia: A rare disorder of ammonia metabolism. ln: R. Preisig. J. Bircher, and G. Paumgartner: The Liver, Quantitative Aspects of Structure and Function, p. 298 (Editor Cantor, Aulendorf, 1976)

9. Remnert, ()., Miale, T., Shukla, J., Latwson, D., and frias, J.: Polvamine concentrations in bone marrow aspirates of children with leukemia and other malignancies. Bloud, 47: 695 (1976).

10. Richards, G. M.: Modifications of the diphenylamine reaction giving increased sensitivity and simplicity in the estimation of DNA. Anal. Biochem. 57: $360(1974)$

Copyright o 1977 Intemational Pediatric Research Foundation, Inc
11. Russell, D). H.: Funtion of Naturally (Ocourring Polyamines (Academic Press, New York, Ionden. 1973)

12. Russell, D). H.: Polyanines in Normal and Neoplastic (irowth (Raven Press New York, 1973)

13. Russell, D. H., and NigeVicker, T. A.: Polyammes in the developing rat and in supportive tissues. Biochem. Biophys. Acta, 25y: 247 (1972).

14. This work was supporfed in part by National Institutes of Health Training Grant A.105680-(1)4 and research grants from the National cystic Fibrosis Research Foundation and the Bochringer Mamnheim Corporation.

15. This proposal was approsed by the Institutional Human Ixperimentation (ommitte and skin biopsies were obtained with informed consent.

16. Requests for reprints should be addressed to: (O. M1. Remert. M.D. Department of Pediatries. Box 1296. University of Florida College of Medicine. Gainesville, Fla. 32610 (USA)

17. Received for publication May 21, 1976.

18. Accepted for publication September 2, 1976.

\title{
A Review: Newer, Noninvasive Cardiac Diagnostic Methods
}

\author{
WILILIAM F. FRILIDMAN, (6;) DAVID) J. SAHIN, ANI) MIICHAEL, J. HIRSCHKLAU
}

Division of Pediatric Cardiology, Department of Pediatrics. University of California, San Dicgo. School of Medicine, La Jolla. Califormia, and the Departme'nt of Pediatrics, University of Arizoma Sichosl of Medicine, Tucsom, Arizona, USA

This review artick will focus on the application of awo noninvasive technigues that have become increasingly more useful in the diagnosis and management of infants and children with heart disease. In a general sense, noninvasive diagnostic technicpues provide two types of information; first, one secks anatomic information in order to more clearly describe the architectural details of the heart and circulation, and, second, one hopes to derive data allowing analysis of functional characteristics of the circulation. The ability to obtain important structure-function correlations by the use of both scintillation scamning and cardiac ultrasound forms the basis for their widespread applicability in noninvasive diagnosis. We will describe selected aspects of current applications of scintillation scanning of the lungs and heart and of echocardiography, and will attempt to indicate new and interesting directions that may be anticipated by continuing developments in these fields. We await, with interest, additions to the armamentarium of the diagnostician that may be expected in the future from electrocardiographic-gated. computerized axial tomograms of the heart and from flow velocity data provided by range-galted, pulsed Doppler technology.

It should be understood that noninvasive methods infrequently offer a substitute for invasive hemodyamic and angiographic studies performed in the cardiac catheterization laboratory. Rather, the former most often provide valuable ancillary datit that assist the clinician appreciably in decisions concerning pationt management.

\section{SCINTILLATION SCANNING}

Isotopes are employed to quantify the distribution of pulmonary blood flow in patients with a wide varicty of acquired and congenital heart discise in order to determine indirectly the levels of pulmonary venous and arterial pressures $(12,1.3)$ and to determine the patency of systemic arteriat and systemic venouspulmonary arterial anastomosis (9.12). In addition to these lung scanning methods which employ radionuclide labeled macroaggregated human serum albumin, radionuclide angiography is utilized to view alterations in the anatomy of the heart and great vessels, and to detect and quantify left to right, intra-, or extracardiac shunts $(2-4,22,3,3,35)$. The latter studies are performed after intravenous infusion of $99^{\mathrm{m}}$ technetium with a scintillation camera coupled to a computer tape storage system,

\section{ALTERATIONS IN REGIONAL PULMIONARY BLOOD FLOW}

\section{VERTICAL DISTRIBUTION OF FLOOW}

The distribution of pulmonary blood flow vertically or to either lung may be determined in an accurate and reproducible manner by scintillation scanning of the lungs (12). The rationale for evaluating the vertical distribution of pulmonary blood flow resides in the importance of distinguishing patients with both pulmonary arterial and venous hypertension from those with pulmonary arterial hypertension alone.

In this regard, more precise selection may be anticipated of patients requiring an accurate hemodynamic assessment of pulmonary flows and resistance. It is recognized that because of the influence of gravity on the low pressure vascular bed, normal crect subjects have greater blood flow to the lung bases than to the apices. In patients with pulmonary venous hypertension, there is a relative increase in blood flow to the apices and a ke ease in perfusion to the lung bases. A linear relationship 